\title{
UTOPIAS DO PÓS-SOCIALISMO \\ Esboços e projetos de reorganização \\ radical da sociedade
}

\section{Luis Felipe Miguel}

Segundo uma perspectiva que já faz parte do senso comum, vivemos uma época de fim das utopias. O colapso do chamado "socialismo real", emblematizado pela queda do muro de Berlim, há quinze anos, deu força à idéia de que não existe

* Uma versão inicial foi apresentada no XXVIII Encontro Anual da Anpocs (Caxambu, outubro de 2004). O texto beneficiou-se dos comentários e sugestões de Regina Dalcastagnè, bem como dos pareceristas anônimos da RBCS, mas continuo como único responsável por eventuais erros e omissões. Ele faz parte da pesquisa "Modelos alternativos de representação política", apoiada pelo CNPq com uma bolsa de Produtividade em Pesquisa.

Artigo recebido em janeiro/2005 Aprovado em maio/2005 no horizonte nenhuma alternativa viável ao capitalismo. Em suas diferentes variedades, unido a alguma forma de democracia eleitoral, ele seria uma condição inextirpável do mundo moderno. A esquerda voltou suas atenções para propostas de aprimoramento do convívio político, sob rótulos como democracia deliberativa (ou radical) e multiculturalismo. No entanto, como anotou Nancy Fraser (1997, p. 2), tais propostas são fracos substitutos para o ideal do socialismo, uma vez que não enfrentam uma questão-chave, a economia política.

De fato, não há disponível nenhuma visão de sociedade alternativa com a penetração e a abrangência que o socialismo, em seus diversos matizes, demonstrou entre, digamos, 1880 e 1980. No entanto, estão em circulação inúmeras propostas utópicas, que reorganizam a vida social por inteiro. Algumas possuem certo impacto no debate político, sobretudo europeu; outras permanecem na condição de meras fantasias intelectuais. Nenhuma alcançou a mesma centralidade 
que o socialismo teve, o que se deve, talvez, menos à incipiência das formulações do que à ausência de conexões com um movimento social. Seu valor, muitas vezes, reside mais na indicação dos pontos problemáticos do ordenamento capitalista e no desafio de pensar diferente do que nas instituições propostas.

Este artigo analisa quatro propostas utópicas, representativas de diferentes correntes de pensamento. Há um projeto de socialismo de mercado, cujo principal teórico é o cientista político estadunidense John Roemer, que busca combinar a pretendida eficiência econômica do mercado com a garantia de real igualdade social, que seria o coração ético do socialismo. Mais ousado, o filósofo franco-austríaco André Gorz quer realizar os objetivos do comunismo desenvolvido, segundo Marx, por meio de uma sociedade de tempo liberado. A universalização da possibilidade de dispor de tempo livre, entendido como tempo de não-trabalho, também está no cerne das propostas de renda básica universal, que encontram diferentes versões e que examino aqui na obra de seu maior expoente, o economista belga Phillipe Van Parijs. De maneira muito mais provocativa, a filósofa britânica Barbara Goodwin concebe uma sociedade lotérica, em que todos os bens sociais seriam distribuídos de forma aleatória e provisória.

Todas as quatro propostas pertencem claramente ao campo da esquerda, na medida em que buscam realizar uma sociedade que amplie a igualdade material de seus integrantes, ficando ao menos implícito que a privação relativa gerada pela desigualdade é um obstáculo para o desfrute da liberdade. Todas também indicam - em maior ou menor medida, mas ao menos indicam que é necessária uma intervenção estatal corretiva permanente, restringindo a esfera das trocas econômicas e, assim, impedindo o retorno da desigualdade.

Como contraponto, uma quinta utopia é acrescentada, correspondendo ao extremo oposto do espectro político. Os anarcocapitalistas desejam a universalização do mercado, que passaria a prover mesmo as funções estatais mais básicas, como justiça e segurança. ${ }^{1}$ Diferindo até de economistas ultraliberais como Ludwig von Mises, Friedrich Hayek, Milton Friedman e James Buchanan - que, no entanto, formam o alicerce intelectual da dou- trina - e de filósofos como Robert Nozick, sem falar de figuras mais bizarras como a influente escritora de ficção científica e líder messiânica Ayn Rand, eles defendem a abolição do Estado. Embora a formulação mais elaborada esteja provavelmente na obra de Murray Rothbard, a melhor síntese foi formulada por outro economista estadunidense, David Friedman (filho de Milton Friedman).

Nas próximas seções, apresentarei e discutirei brevemente as cinco correntes, resumindo suas diferenças na conclusão. Começo com os anarcocapitalistas, passando em seguida pelo socialismo de mercado, sociedade de tempo liberado, renda básica universal e, por fim, sociedade lotérica, numa ordem que segue apenas os caprichos da argumentação. Antes, porém, é necessário entender o significado de "utopia" e situar a discussão em outra, mais ampla, sobre justiça e organização social.

\section{Justiça e utopia}

Embora seja arriscado fazer esse tipo de avaliação sem um prévio estudo aprofundado, é razoável pensar que a carga semântica associada à palavra utopia é antes negativa do que positiva. À direita, há a célebre crítica de Karl Popper ao caráter inerentemente totalitário do pensamento utópi$\mathrm{co}$, que "tenta realizar um estado ideal, usando um projeto de sociedade como um todo; e isso exige o forte regime centralizado de uns poucos" (Popper, 1974 [1945], vol. I, p. 175). Uma crítica que vai reaparecer, por exemplo, em Ralf Dahrendorf, para quem a utopia "é, pela natureza da idéia, uma sociedade totalitarista" (Dahrendorf, 1991 [1990], p. 81); e que é desenvolvida sobretudo por Robert Nozick, crítico do caráter uniformizante e inflexível da utopia, uma sociedade "estática e rígida, sem oportunidades ou expectativas de mudança ou progresso e nenhum meio de seus próprios habitantes escolherem novos padrões" (Nozick, 1991 [1974], p. 352).

À esquerda, o utopismo foi anatematizado por Marx, que o via como uma etapa anterior do pensamento operário, superada na época do socialismo científico. Enquanto os utopistas fantasiavam sobre a sociedade futura, Marx julgava que era necessário depreendê-la do movimento histórico real: 
Para nós, são utopistas aqueles que separam as formas políticas de seu fundamento social e as apresentam como dogmas abstratos e gerais. [...] $\mathrm{O}$ comunismo alemão é o inimigo mais determinado de todo utopismo e, longe de excluir o desenvolvimento histórico, ele se funda em primeiro lugar sobre tal desenvolvimento (Marx, 1976 [1848], p. 79).

Embora, no seio do socialismo ou mesmo do marxismo, seja possível encontrar pensadores que concedem uma valoração positiva à utopia, como Ernst Bloch, a vertente dominante parece ser a adesão ortodoxa ao campo oposto, da "ciência". ${ }^{2}$ A linguagem corrente, por sua vez, associa utopia e utópico predominantemente ao sentido de "irrealizável" e "quimérico".

Neste artigo, no entanto, uso o termo utopia de uma forma que se pretende agnóstica em relação à viabilidade das propostas de transformação da sociedade. Utopia adquire o significado de um norte para a organização/reorganização da estrutura social: "a visão de futuro sobre a qual uma civilização baseia seus projetos, estabelece seus objetivos ideais e constrói suas esperanças" (Gorz, 1988, p. 22). A definição realça o aspecto de indeterminação histórica e o caráter normativo da proposta utópica. No sentido que Gorz empresta ao termo, uma utopia provavelmente não será passível de concretização plena. Mas é útil por fornecer diretrizes que orientam a produção de uma nova sociedade, mais próxima do ideal. A utopia direciona a ação política e potencializa a insatisfação com o mundo existente.

Um crítico da utopia - neste sentido da palavra - pode argumentar que a busca do ideal inatingível acaba por fechar os olhos do utopista para ações mais corriqueiras que podem surtir efeitos benéficos no imperfeito mundo concreto (Nove, 1989 [1983], pp. 364-365). A resposta a esta crítica passa pela demonstração do caráter realista da utopia, que deve ser uma extrapolação a partir de um movimento real. O "político em ação" da fórmula de Antonio Gramsci define o utopista no sentido proposto por Gorz: "O político em ação é um criador, um suscitador; mas não cria do nada, nem se move no vazio túrbido dos seus desejos e sonhos. Baseia-se na realidade fatual" (Gramsci, 1929-1935, p. 43).
Por outro lado, é preciso observar que a denúncia do caráter totalitário da utopia, feita pelo pensamento conservador, exclui, ela própria, o dever-ser da esfera política. Como afirma um historiador do pensamento utópico,

[...] a invenção utópica mostra-se cúmplice da invenção do espaço democrático. De fato, é apenas com a invenção deste espaço que a sociedade se dá a representação de ser fundada apenas sobre ela mesma, sobre sua "vontade" livremente expressa e fundadora de sua ordem. De pronto, este espaço se oferece como um espaço social a modelar, a gerar, a reinventar (Baczko, 1984, p. 144).

A narrativa utópica afirma a sociedade humana como auto-instituída, isto é, regida por normas que as mulheres e os homens se deram e, se quiserem, podem modificar. Em qualquer projeto político transformador existe, ao menos em germe, a projeção de uma sociedade nova, que nunca se realizou. Caso isto não esteja presente, a disputa política se reduz à mera alocação de recursos. ${ }^{3}$

Considerando adequada a caracterização das propostas em discussão como utópicas, é possível passar para a análise de sua relação com o debate sobre justiça, que é um dos eixos principais da teoria política das últimas décadas. Seu ponto de partida é, como se sabe, Uma teoria da justiça, o influente livro de John Rawls (1997 [1971]), que suscitou uma diversidade de interpretações e polêmicas. Sem entrar nos meandros da teoria rawlsiana e, muito menos, nas transformações que ela sofre até se cristalizar numa síntese posterior (Rawls, 2000 [1993]), é razoável destacar dois aspectos. Primeiro, embora seja delineada uma estrutura básica justa para a sociedade em termos bastante abstratos, ela se ajusta bem à combinação entre economia capitalista e Estado de bem-estar. De fato, apesar de Rawls produzir uma teoria igualitária da justiça, o princípio da diferença admite desigualdades que, no final das contas, revertem em favor dos mais desafortunados - o que é a justificativa padrão para a manutenção da propriedade privada e da competição mercantil, que combateriam a preguiça e a acomodação, beneficiando a inovação, o progresso e a prosperidade para todos. Os mecanismos de bem-estar, por sua vez, garantem a cada um o usufruto das liberdades básicas. 
Os pensadores à direita, entre os quais se destacou Nozick, criticaram Rawls por ele se comprometer com um padrão final de distribuição que exigiria uma intervenção constante para retificar os resultados da livre interação dos agentes (Nozick, 1991 [1974], cap. 7). De acordo com esta concepção, dado um ponto de partida equânime, seguido por trocas livres, qualquer resultado alcançado deve ser considerado como justo - ainda que o azar ou a incompetência condenem alguns a situações muito piores do que as de outros. O pensamento utópico e o modelo de Rawls são criticados indistintamente, por afetarem a liberdade dos agentes na busca por uma padrão "adequado" de distribuição dos bens sociais.

À esquerda, a igualdade postulada pela teoria rawlsiana da justiça é, em geral, julgada insuficiente. Nem todos os autores, cujas propostas utópicas são discutidas aqui, se engajaram numa interlocução explícita com Uma teoria da justiça é mais clara em Barbara Goodwin e em Philippe Van Parijs, cuja defesa mais conhecida da renda básica universal nasce em resposta a um artigo de Rawls (Van Parijs, 1997 [1991]) -, mas ela está presente em todo o ambiente da discussão.

O segundo aspecto a ser destacado, ainda mais importante para a presente discussão, é que o esforço de Rawls se dirige à formulação de uma teoria da justiça que seja neutra em relação às diversas concepções de bem existentes na sociedade. A boa sociedade não é aquela que realiza algum valor, mas a que permite que cada um persiga livremente o bem que deseja. A neutralidade valorativa de Uma teoria da justiça foi questionada, uma vez que se apóia em pressupostos fortemente individualistas (e que faz implicitamente da tolerância a virtude social por excelência). De maneira ainda mais aguda, o artifício apresentado por Rawls para alcançar a neutralidade - a famosa posição original, sobre a qual se estende o "véu da incerteza" quanto às preferências individuais foi acusado de introduzir concepções insustentáveis sobre a constituição do self e a relação entre indivíduos e coletividades (Sandel, 1998).

Como norma, no entanto, a busca da neutralidade valorativa triunfou. Com duas notáveis exceções - a proposta de sociedade de tempo liberado de Gorz e a sociedade lotérica de Goodwin -, as utopias aqui analisadas manifestam-se como neutras em rela- ção aos valores que realizariam. Elas permitiriam a ampliação do espaço de liberdade de cada indivíduo, que então buscaria promover seus próprios objetivos. Gorz, ao contrário, preenche essa busca com um conteúdo - o autodesenvolvimento humano - revelando, assim, sua vinculação com a tradição marxista. E Goodwin recusa validade à própria idéia de uma concepção pessoal de bem, estabelecendo como valor a diversidade de experiências de vida.

Cabe notar, por fim, que as propostas aqui caracterizadas como utópicas desenvolvem as instituições sociais que gostariam de ver implantadas com muito maior detalhamento do que fazem Rawls e teóricos similares. Mais do que princípios abstratos, elas indicam mecanismos concretos que gerariam determinados efeitos. O plano, decerto, é apresentado com grande dose de vagueza e o reconhecimento de que ainda restam muitos passos antes de ser possível levá-lo à prática; nada próximo de um Fourier, que já assinalava os quarteirões de Paris em que seriam erguidos os seus falanstérios. Ainda assim, há uma diferença marcante, que permite lhes atribuir o adjetivo "utópicas" como característica distintiva em relação a construções teóricas mais abstratas.

\section{Mercado sem Estado}

Um dos traços fundantes do pensamento liberal, em suas diversas vertentes, é a contraposição entre o espaço das relações impositivas (o Estado) e o espaço das trocas consensuais entre agentes livres (o mercado); ou, para usar as palavras de Milton Friedman (1985 [1962], p. 21), a "direção central usando a coerção" e a "cooperação voluntária dos indivíduos". Aceitando esta caracterização das duas esferas e também o pressuposto de que a liberdade individual é o bem a ser maximizado, segue-se que o Estado deve ser minimizado - o menor Estado que seja capaz de garantir a continuidade da vida social é o melhor possível. O problema é saber onde se encontra este mínimo, que às vezes pode ser bastante alargado. No protoliberalismo de Thomas Hobbes, por exemplo, as forças centrífugas presentes nas coletividades humanas são tão poderosas que, para alcançarmos um mínimo de coesão social, precisamos abdicar a quase toda liberdade pessoal. 
Os anarcocapitalistas chegam à conclusão oposta: o Estado pode ser abolido, não como no sonho de anarquistas e comunistas, porque suas funções seriam desempenhadas pela livre associação dos produtores, mas porque todas as funções do Estado seriam assumidas pelo mercado. O raciocínio subjacente às suas propostas é de uma simplicidade estonteante; um de seus divulgadores diz que se limita a levar algumas afirmações familiares da retórica política "à sua conclusão natural" (D. Friedman, 1989 [1973], p. xiii). A simplicidade, que consiste muitas vezes em ignorar quaisquer efeitos colaterais e não recuar um milímetro da estrita aplicação de um número reduzido de princípios, é a fonte do fascínio que o projeto anarcocapitalista desperta em muita gente - e também, é claro, de muito de sua fraqueza teórica.

O primeiro princípio é o antipaternalismo, que se expressa na crença absoluta na máxima utilitarista de que cada um é o melhor juiz de seus próprios interesses ${ }^{4}$ - isto é, qualquer medida que implique uma proteção externa às pessoas é inaceitável. Isto inclui, por exemplo, a proibição de determinadas drogas, o veto ao comércio de órgãos ou a imposição do uso de cinto de segurança, mas também a previdência social compulsória ou a legislação trabalhista. Se alguém prefere consumir toda sua renda a garantir algum tipo de aposentadoria no futuro, trata-se de uma decisão presumivelmente esclarecida e cabe ao próprio indivíduo arcar com as conseqüências, esperando pela caridade alheia ou, caso esta esteja ausente, padecendo de privações na velhice. Da mesma forma, trabalhadores e patrões são livres para aceitarem ou não os termos de seus contratos, sendo inadmissível que existam cláusulas impostas externamente. ${ }^{5}$

Um pensador liberal mais sofisticado, como Stuart Mill, debate-se com o problema das conseqüências sociais das decisões individuais, o que o leva a buscar o melhor equilíbrio entre o máximo de liberdade pessoal e a manutenção do bemestar coletivo (Mill, 1991 [1859]) - uma questão que não existe para os anarcocapitalistas, com sua visão atomística da sociedade. Essa visão também exila a solidariedade como componente atuante e necessário dos agregados humanos; mesmo que ela possa existir, na forma da caridade ou do amor ao próximo, trata-se sempre de uma escolha pessoal do agente, reversível a cada momento (D.
Friedman, 1989 [1973], pp. 15-16). Não há nada que implique a responsabilidade mútua entre os participantes de uma mesma sociedade. Por fim, é uma moldura teórica que impede que se coloque em pauta a formação das preferências, vistas implicitamente como emanações naturais de cada indivíduo.

O princípio que complementa o antipaternalismo é a inviolabilidade da propriedade privada, um conceito que se estende o suficiente para incluir o controle sobre o próprio corpo e, dessa forma, todas as liberdades individuais. Trata-se de uma versão do "individualismo possessivo", identificado no pensamento de Hobbes e Locke por Macpherson (1962): meu corpo é minha propriedade e, se eu posso movimentá-lo livremente, é porque posso dispor livremente de todas as minhas propriedades. Daí já se depreende o corolário da ausência de Estado, uma vez que a extração compulsória de impostos, sem a qual nenhum Estado sobrevive, atinge a propriedade privada. Sobretudo, a intervenção estatal, regulando o comportamento dos indivíduos, fere sua liberdade.

Os ultraliberais têm em comum a proposta de redução extrema das áreas da vida social em que o Estado se faz presente, mesmo aquelas em que a ação estatal é considerada indispensável por quase todos. Milton Friedman, por exemplo, não julga adequado coibir o que hoje se chama de "exercício ilegal da medicina": se alguém se faz passar por médico e prejudica um doente, "trata-se de exemplo de contrato voluntário, e de trocas entre o paciente e o médico. Sob esse ponto de vista, não há motivo para intervenção" (1985 [1962], p. 135). Como princípio abstrato, caberia ao Estado apenas garantir o cumprimento dos contratos e proteger os cidadãos contra o uso da força por parte de outros: "o Estado mais amplo [do que o mínimo] violará os direitos das pessoas" (Nozick, 1991 [1974], p. 9). Apenas como princípio abstrato, convém notar, já que na prática (e a associação de Milton Friedman com o regime de Pinochet serve de perfeita ilustração) seus aplausos costumam ir para Estados altamente repressivos, que coíbem a ação dos grupos que perturbariam o funcionamento do mercado, como os sindicatos de trabalhadores.

A diferença dos anarcocapitalistas é que eles julgam que mesmo essas funções mais básicas podem ser cumpridas pelo mercado. David Fried- 
man e Murray Rothbard imaginam um esquema em que agências privadas de proteção venderiam seus serviços aos particulares, cumprindo as funções hoje reservadas a organismos estatais como a polícia. Já que existiriam várias firmas competindo entre si, todas teriam incentivos para prover os melhores serviços aos menores custos. Numa sociedade livre, a proteção

[...] deve ser suprida por pessoas ou firmas que (a) ganham seu rendimento voluntariamente, e não por coerção, e (b) não se arrogam, como fazem os Estados, um monopólio compulsório da polícia ou da proteção judicial. Apenas esta provisão libertária do serviço de defesa seria compatível com um mercado livre e uma sociedade livre. Assim, firmas de defesa deveriam ser tão livremente competitivas e não-coercivas contra não-invasores quanto todos os outros fornecedores de bens e serviço no mercado livre. Serviços de defesa, da mesma forma que todos os outros serviços, seriam vendidos no mercado e apenas vendidos no mercado (Rothbard, 1970, pp. 1-2).

O risco de uma guerra entre as agências de proteção também é esconjurado graças às virtudes intrínsecas do mercado: guerras são custosas e, portanto, empresas que visam ao lucro as evitariam (D. Friedman, 1989 [1973], p. 116). Em vez da guerra, elas buscariam árbitros para resolver os conflitos. Mais uma vez, haveria um mercado competitivo de árbitros, isto é, de sistemas legais e de cortes de justiça. Os árbitros fazem a lei, as agências de proteção escolhem árbitros caso a caso, para cada um de seus conflitos, e os indivíduos privados escolhem agências de proteção. (Um modelo similar geraria um mercado de padrões monetários concorrentes.)

As deficiências do modelo são evidentes - as respostas a uma questão mais espinhosa, por exemplo a possibilidade de as agências tiranizarem seus clientes, "vendendo" proteção à maneira da Máfia, são sempre insuficientes. Baseiam-se na crença não-embasada de que a ação "honesta" é sempre mais lucrativa do que a criminosa (Idem, pp. 121-122) ou, então, de que o mercado é em si mesmo um sistema de controle, com as agências concorrentes se mobilizando para impedir a ação da que se tornou fora-da-lei (Rothbard, 1970, p. 5). Mesmo dentro do campo do ultraliberalismo, foi demonstrado que há uma tendência natural de transformação da proteção (e da lei) num monopólio, caso em que está formado um Estado de fato (Nozick, 1991 [1974], pp. 27-32).

Há ainda o problema da defesa externa, outra área em que mesmo os ultraliberais reconhecem a necessidade da presença estatal (monopolística, aliás). David Friedman o deixa em suspenso e apresenta o único momento de dúvida de sua construção teórica, admitindo que talvez alguma forma rudimentar de Estado fosse inevitável enquanto persistisse a ameaça soviética (D. Friedman, 1989 [1973], cap. 46).

Assim, a obstinação cega com que os anarcocapitalistas se aferram a seus princípios faz com que sua teoria tenha um grande grau de simplicidade - tudo é apenas deduzido de uns poucos argumentos iniciais. A principal pressuposição, de que as trocas mercantis são sempre livres de coerção e mutuamente vantajosas (Rothbard, 1962, vol. I, pp. 71-72), nunca é questionada. Mas mesmo para o mercado ideal com que operam a afirmação é insustentável; e os mercados reais estão sempre muito longe do ideal (ver Boron, 1994 [1991]). A desigualdade material representa uma séria limitação das possibilidades de ação para os que estão no seu pólo negativo, constrangendo-os ao engajamento em trocas que, em outras circunstâncias, não aceitariam. Na ausência de qualquer mecanismo de proteção social ou de distribuição de riqueza, que o modelo veta expressamente, uma parcela significativa da população ficaria em situação de penúria.

Um subtexto importante do argumento dos anarcocapitalistas, assim como de outros ultraliberais, é a denúncia da democracia. Sua inferioridade como forma de alocação de recursos é ressaltada com freqüência, com auxílio de uma literatura próxima, que assinala a irracionalidade inerente aos processos de decisão pelo voto (Riker, 1982). As decisões democráticas ferem o dogma da liberdade individual, pois são impostas a todos, mesmo aos que discordam delas, e tendem a ser irresponsáveis, na medida em que o voto é um recurso sem custos para quem o usa. Além disso, num argumento surpreendente, David Friedman (1989 [1973], p. 104) diz que a democracia maximiza as desigualdades, em comparação com o mercado. Afinal, se eu tenho o dobro da renda de outra pessoa, eu 
posso comprar apenas o dobro de bens, não todos; mas quem pertence a um partido com o dobro de votos vence todas as eleições. O argumento é especialmente capcioso, quaisquer que sejam as críticas que as democracias majoritárias possam merecer: um partido torna-se vitorioso com os votos de uma multiplicidade de pessoas, ao passo que a riqueza pode estar concentrada nas mãos de um único ou de pouquíssimos indivíduos.

$\mathrm{Na}$ utopia anarcocapitalista, todas as relações interpessoais são, em princípio, instrumentais. Os laços entre os indivíduos se resumem àqueles que eles estabelecem voluntariamente, por intermédio de seus contratos. Esta total independência, imagina-se, leva ao máximo de liberdade, sempre entendida em seu sentido negativo, de ausência de coerção externa. Os benefícios esperados, portanto, concentram-se na ampliação da liberdade individual. Os argumentos que, por vezes, indicam os benefícios econômicos esperados pela ausência de intervenção estatal na esfera produtiva são estritamente secundários. A sociedade esperada - se é que o termo "sociedade" ainda se aplica de maneira legítima - é vantajosa por ser livre, e continuaria sendo vantajosa caso, por algum motivo, se tornasse menos próspera.

Como desenho de uma nova forma de organização humana, a proposta exige uma transformação bastante radical do mundo que temos hoje. Friedman e Rothbard não se preocupam com a questão da transição - como, partindo das sociedades atuais, poderemos chegar na utopia. O caráter radicalmente anticonservador do anarcocapitalismo é expresso na afirmação de que, como o pior que pode acontecer é ter que reestabelecer o Estado, nada se perderia tentando (Rothbard, 1970, p. 6). Trata-se da perfeita negação do elemento central do credo do conservadorismo político, de Burke a Oakeshott, que é o entendimento da fragilidade da construção de uma ordem social estável, fruto da experiência acumulada de gerações, e, portanto, da necessidade da maior cautela ao alterá-la.

\section{Socialismo de ações}

Para os anarcocapitalistas, como visto, o valor do mercado reside antes na liberdade que ele proporciona do que em sua eficiência superior. O mesmo é verdade para outros liberais extremados. Em meados do século XX, esta era a linha principal de argumentação dos integrantes da Sociedade de Mont Pèlerin, como se evidencia pela leitura do panfleto fundador sobre $O$ caminho da servidão (Hayek, 1944). Sua doutrina foi construída no momento em que políticas de intervenção estatal levavam o capitalismo a uma fase de acelerado crescimento (Anderson, 1995), ao mesmo tempo em que os países do socialismo real, sob regime de planejamento centralizado, também experimentavam um rápido desenvolvimento econômico. Não era nada evidente, muito pelo contrário, que a competição mercantil fosse a forma mais eficaz de organização econômica.

Décadas depois, com a estagnação e o fim do socialismo real e a crise do modelo keynesiano de gestão do capitalismo, firmou-se rapidamente um quase consenso de que os mecanismos de mercado eram imprescindíveis para a condução eficiente da economia e que, por trás da "anarquia da produção capitalista" criticada pelo marxismo, escondia-se uma racionalidade sutil que nenhuma outra forma de gestão seria capaz de alcançar. A concorrência garantiria, sobretudo, o incentivo à inovação e o feedback sobre as preferências do público. Mesmo adversários do capitalismo julgavam necessário garantir o funcionamento do mercado numa sociedade alternativa. Ao contrário dos liberais, não depositavam fé em suas virtudes emancipadoras e temiam a desigualdade gerada por ele. O mercado era tido como necessário exclusivamente por seus efeitos na produção econômica.

A questão que se impõe, desta perspectiva, é como conciliar uma economia mercantil com a igualdade social. As soluções mais simples são também as que apresentam com maior nitidez suas deficiências. Por exemplo, impor um teto ao crescimento das empresas, como propôs Miliband (1994), significa refrear o incentivo à inovação exatamente daqueles que se mostraram mais eficientes.

A proposta de John Roemer (1994, 1996) é uma tentativa criativa de superar o problema. Em resumo, seu projeto de socialismo com mercado passa pela universalização da propriedade dos meios de produção, mediante um sistema engenhoso que isola o mercado de capitais do mercado 
de bens de consumo. Existiriam dois tipos de moeda em circulação na sociedade. Com uma, o dinheiro comum, seriam pagos os salários e comprados os bens de consumo. A outra ("cupons") serviria apenas para a aquisição de ações de empresas. Para os cidadãos, as duas moedas seriam estritamente inconversíveis entre si. Apenas as firmas poderiam trocar cupons por dinheiro do Tesouro, para investir. Trata-se, portanto, de um retorno à idéia de pluralidade monetária, presente no debate político ao menos desde os anos de 1930, quando foi lançada na França por Jacques Duboin.

Os cupons seriam distribuídos de forma igualitária; cada cidadã ou cidadão receberia uma certa quantidade ao nascer (ou ao atingir a maioridade), para ingressar no mercado de ações. De acordo com a competência e a sorte com que fossem feitos os investimentos, o indivíduo alcançaria menor ou maior participação no mercado; porém, não poderia utilizar seu dinheiro-de-consumo para comprar mais ações. Aquelas que possuía, por sua vez, poderiam ser reconvertidas em cupons, mas não seriam transmitidas a outras pessoas por nenhum meio - nem venda, nem doação, nem herança. A propriedade das ações geraria o direito de receber dividendos, estes sim em forma de dinheiro-de-consumo, e de eleger ao menos parte da direção da empresa.

No modelo, os incentivos da competição mercantil estão plenamente mantidos, para empresas e investidores. Estes últimos preferirão investir nas firmas que apresentam melhores perspectivas de geração elevada e continuada de dividendos. As empresas, por sua vez, precisam apresentar um desempenho satisfatório para atrair os investidores. Além disso, o direito de participação na escolha da direção garante que nenhuma firma será indiferente aos interesses daqueles que nela investiram os seus cupons.

O modelo também garantiria a realização do socialismo. Não a forma tradicional de socialismo, que exige a propriedade pública dos meios de produção, mas pelo menos a realização daqueles que seriam os três objetivos principais de uma sociedade socialista, definidos como igualdade de oportunidades para a auto-realização e o bemestar, igualdade de oportunidades para a influência política e igualdade de status social (Roemer, 1996, p. 10). O primeiro objetivo seria uma igual- dade de oportunidades para a auto-realização e o bem-estar, não a igualdade efetiva, pois, caso contrário, seria necessário despender recursos sociais gigantescos para aqueles que buscassem objetivos demasiado caros e irrealistas. Assim, cabe a cada um optar por formas de realização pessoal e padrões de bem-estar mais razoáveis. A influência política também só é igualitária na oportunidade, na medida em que dependerá da escala de prioridades de cada cidadã ou cidadão o esforço despendido para transformá-la em presença real na arena política.

Apenas a igualdade de status é substantiva. O resultado é um ideário socialista bastante similar ao liberal, no qual também é valorizada a existência de oportunidades iguais, complementada pela igualdade "perante a lei", isto é, uma igualdade de status legal. Embora o valor da igualdade de oportunidades não seja desprezível, ela é compatível com uma desigualdade real gritante. Como observa Phillips (1999, p. 60), "uma igualdade de recursos inicial, combinada com uma oportunidade igual de fazer o que quisermos com eles, não é capaz de satisfazer os requerimentos da igualdade" real. A autora está comentando propostas como a de Ronald Dworkin, que enfatizam a responsabilidade moral pelas escolhas, mas a crítica vale também para a utopia de Roemer.

Como o espaço da política está em aberto em seu projeto, nada impede a construção de uma rede de proteção social, ao estilo do Welfare State. Mas tampouco algo o exige. $\mathrm{Na}$ ausência até mesmo de uma cláusula rawlsiana de diferença, o socialismo de ações pode lançar na miséria aqueles que manejaram mal seus investimentos, enquanto os mais habilidosos ou afortunados ficarão ricos com os dividendos recebidos. Seus filhos não receberão uma parcela maior do controle das empresas, já que cupons ou ações não são transmissíveis por herança, mas herdarão outras propriedades e serão beneficiados pelas vantagens advindas da condição material dos pais - educação de qualidade superior, acesso a bens culturais etc.

Como solução parcial para esses problemas, Roemer estabelece que os investimentos não seriam feitos em empresas específicas, mas obrigatoriamente em fundos mútuos, administrados por especialistas. A medida contempla dois objetivos. O primeiro, "paternalista", é impedir que os 
cidadãos invistam muito mal os seus cupons. $\mathrm{O}$ segundo é evitar que surjam firmas de fachada, que reinvistam muito pouco ou quase nada e gerem muitos dividendos, o que seria uma forma disfarçada de conversão dos cupons em dinheirode-consumo (1996, p. 21). A preocupação é voltada sobretudo para os mais velhos, que - dada a proibição da herança dos cupons - teriam um horizonte temporal drasticamente reduzido e pouquíssimo incentivo para aguardar retornos de longo prazo. ${ }^{6}$ Portanto, os fundo mútuos são obrigados a incluir investidores de idades variadas.

A obrigatoriedade dos fundos mútuos reduz os benefícios esperados pelo modelo, uma vez que a figura do investidor ousado e inovador, apostando na multiplicação do seu próprio patrimônio, é substituída pelo gerente de fundos, burocrata que cuida da riqueza alheia. A participação do cidadão-acionista na gestão das empresas também é descartada, substituída por um implausível monitoramento dos fundos (Simon, 1996, p. 53). Além do mais, o gerente é pressionado para adotar uma postura mais conservadora, já que uma de suas funções é impedir a dilapidação dos investimentos dos cotistas.

O mix de investidores de idades diferentes nos fundos não impediria uma preferência generalizada por retornos rápidos, isto é, pela conversão dos cupons em dinheiro-de-consumo. Os mais jovens podem receber grandes dividendos de imediato e aplicar o dinheiro para consumo futuro (Idem, pp. 47-48) - isto sem levar em conta um viés muito comum na escala de preferências, que leva os indivíduos a optar por uma gratificação imediata e segura em lugar de outra, posterior e incerta, ainda que maior. Em suma, a proposta exige tamanho controle público, para evitar fraudes ou irracionalidade excessiva no investimento, que as vantagens esperadas em termos de inovação e concorrência tendem a desaparecer.

Há ainda o problema da transição. Embora, como diz um crítico, seja "autoconscientemente conservadora pelos padrões socialistas", ainda assim a proposta exige uma transformação social radical, que afeta os interesses cruciais da classe capitalista (Brighouse, 1996, p. 192). Afinal, é necessário expropriar os meios de produção, antes de distribuir seu controle entre a população, por meio dos cupons. De início, Roemer imaginava que as sociedades em transição do mundo excomunista estariam em boas condições para implementar o projeto. Nelas, não havia nenhum capitalista privado a ser prejudicado; era a propriedade pública que seria distribuída. Mas aquele momento histórico passou.

As críticas mais graves à proposta de Roemer, porém, dizem respeito aos valores que ela promove. De forma geral, o socialismo de mercado é criticado por remover apenas uma fonte de injustiça e desigualdade (a propriedade do capital), mantendo outras, como as causadas pela diferença de talentos; e, sobretudo, por manter um "misto de ganância e medo" como motivação para os atores econômicos (G. A. Cohen, apud Callinicos, 2000, p. 121). Isto é insatisfatório porque, no ideal que norteia seus projetos de reconstrução da sociedade, os socialistas buscam "não apenas novas formas de propriedade, mas também um novo mecanismo dirigente, uma nova racionalidade, uma nova lógica econômica" (Wood, 1995, p. 292).

O socialismo de ações não contempla nada disso. Como observa um de seus comentaristas, enquanto alguns socialistas julgam que o mercado pode ser permitido para sanar falhas do controle democrático da economia, para Roemer é o contrário: as relações mercantis predominam, com as intervenções democratizantes servindo para corrigir eventuais desfuncionalidades (Wright, 1996, pp. 123-124).

Sua utopia prevê a manutenção, entre os agentes econômicos, das mesmas motivações existentes sob o capitalismo - como se elas não pudessem ser transformadas, isto é, como se as motivações humanas fossem dissociadas das instituições sociais existentes. De fato, na medida em que todos se tornariam jogadores da bolsa de valores, ela criaria uma "cultura de loteria", pouco compatível com a solidariedade ou com a participação política ampliada (Simon, 1996, pp. 51-52).

Em comparação com outros projetos utópicos - como o de Gorz, analisado na próxima seção -, o de Roemer mostra-se mais "realista" e também mais factível, em especial se é deixado de lado o problema da transição. Sua sociedade é moldada para o indivíduo auto-interessado da filosofia utilitarista, em busca da ampliação de seus benefícios ao menor custo. O preço a pagar pelo "realismo", porém, é alto. Objetivos como a supe- 
ração da alienação e do fetichismo da mercadoria, a ampliação da liberdade individual ou mesmo a igualdade material substantiva são deixados de lado, em prol da promoção de um único e limitado valor, a igualdade de oportunidades.

\section{A sociedade dual}

Do ponto de vista dos valores que promove, do ideal que deseja alcançar, a utopia proposta por André Gorz representa uma atualização do comunismo desenvolvido marxista. A sociedade dual que ele propõe, na qual o tempo livre é o maior bem social, apresenta-se, tal qual o comunismo de Marx, como uma possibilidade histórica aberta pelo desenvolvimento das forças produtivas. Num caso como no outro, a nova sociedade propiciaria a superação da alienação e a realização das múltiplas potencialidades dos seres humanos. Embora os sobrelanços utópicos sejam maiores em Marx do que em Gorz - Marx tende a ver o comunismo como uma inevitabilidade histórica e desenha-o com um nível muito mais elevado de auto-realização dos indivíduos -, o sentido ético é o mesmo (Miguel, 1999b).

Seguindo Josué Pereira da Silva (2002), é razoável distinguir três momentos na obra de Gorz. Os primeiro livros, redigidos nos anos de 1950, têm uma perspectiva sartreana e foco no problema da alienação. A segunda fase preocupa-se com a formulação teórica de uma estratégia revolucionária apropriada para as sociedades capitalistas desenvolvidas, nas quais a classe operária deixou de viver em situação de pobreza extrema. Após um período de transição, em meados dos anos de 1970, quando publicou obras com preocupação ecológica, o terceiro momento da reflexão de Gorz é inaugurado com Adeus ao proletariado, em 1980. É quando ele rompe com a identificação do proletariado como agente revolucionário, questiona a centralidade do trabalho nas sociedades contemporâneas e apresenta seu projeto utópico.

Ele parte da avaliação de que o desenvolvimento recente das forças produtivas, sobretudo com a informática e a automação, tornou possível, pela primeira vez na história da humanidade, o triunfo - ainda que parcial - da liberdade sobre a necessidade. A reprodução de "uma sociedade viável, que disponha de tudo o que é necessário e útil à vida", exige cada vez menos trabalho (Gorz, 1980, p. 91). Mas o surgimento das condições materiais que permitem libertar mulheres e homens de uma grande parcela do fardo do trabalho não reverteu concretamente em ampliação da liberdade para os trabalhadores. Há, de um lado, a permanência da "ideologia do trabalho", que faz do pleno emprego a bandeira mais importante do movimento sindical. E, de outro, as classes dominantes têm interesse na manutenção das relações de dominação que caracterizam o trabalho assalariado.

O resultado é uma situação sem sentido mas cujo nonsense por vezes nos escapa, tão corriqueira se tornou: o trabalho deixou de ser meio para se tornar fim, isto é, a sociedade produz para trabalhar (para "gerar empregos"), em vez de trabalhar para produzir (Idem, p. 92). O reconhecimento cabal desse paradoxo deve levar à constatação de que é necessário substituir a busca do pleno emprego por um projeto de sociedade mais condizente com as novas realidades produtivas. Tal projeto é, para Gorz, o de uma "sociedade dual".

A proposta prevê a criação de dois setores produtivos distintos, um "autônomo" e outro "heterônomo". O setor heterônomo da economia permaneceria guiado pela necessidade, com produtores subordinados e trabalho anônimo, indiferenciado. Utilizando as mais modernas técnicas industriais, este setor produziria em massa os produtos essenciais, que seriam distribuídos a toda população. Todo o cidadão teria o dever de fornecer algumas horas de trabalho socialmente útil, produzindo no setor heterônomo. Gorz fala em 20 mil horas de trabalho em toda a vida - contra as mais de 57 mil horas atuais de alguém que trabalhe quarenta horas por semana, durante trinta anos, onze meses por ano. $O$ indivíduo poderia concentrar suas horas "socialmente úteis" em períodos de trabalho intenso ou dispersá-las em parcelas diárias suaves.

Esse setor heterônomo (ou alienado) é imprescindível porque "as forças produtivas desenvolvidas pelo capitalismo trazem a sua marca impressa a tal ponto que não podem ser geradas ou colocadas em operação segundo uma racionalidade socialista" (Idem, p. 26). A alienação é inerente à fábrica com linha de montagem - e, ao mesmo tempo, esta fábrica é necessária por 
proporcionar economias crescentes de trabalho humano. Não se trata, portanto, da apropriação capitalista: a lógica própria da grande indústria é alienante. $\mathrm{O}$ trabalho morto força o trabalho vivo a servi-lo. "Em resumo", diz Gorz, sumarizando teses de Marx sobre a grande indústria, "o processo de dominação da natureza pelo homem (através da ciência) torna-se a dominação do homem pelo processo de dominação" (Gorz, 1988, p. 74, ênfase suprimida). ${ }^{7}$

Ele acredita que "a única chance de abolir as relações de dominação é reconhecer que o poder funcional é inevitável e conceder-lhe um lugar circunscrito" (Gorz, 1980, p. 81). O trabalho heterônomo seria restrito à sua esfera imprescindível - a grande indústria - permitindo o surgimento de um setor livre, de trabalho autônomo, que propiciaria a auto-realização humana. Nele são abolidos ou minimizados os critérios "econômicos" de produtividade, eficiência e massificação. A atividade é criativa, porque ali se produz o que não é necessário:

As atividades do tempo livre, na mesma medida em que são produtivas, têm como objeto a autoprodução do facultativo, do gratuito, do supérfluo, em suma, do não-necessário que dá à vida seu sabor e seu valor: tão inútil quanto a vida mesma, ele [o "não-necessário"] a exalta como o fim que funda todos os fins (Gorz, 1983, p. 117).

No tratamento que dá à relação entre os dois setores da economia, Gorz reelabora uma idéia presente em O capital: é além do trabalho determinado pela necessidade que "começa o desenvolvimento das forças humanas, considerado um fim em si mesmo, o verdadeiro reino da liberdade, que, porém, só pode florescer com aquele reino da necessidade como sua base" (Marx, 1988 [18611879], livro III, p. 1044). A proposta de sociedade dual também apresenta amplas semelhanças com Habermas; a manutenção de um setor de trabalho heterônomo corresponde, na obra de Habermas, ao reconhecimento da legitimidade de uma esfera dominada pela razão instrumental, o mundo sistêmico (das relações econômicas e de poder). A esfera da atividade autônoma, na qual Gorz enfatiza os aspectos da convivencialidade, é similar ao "mundo-da-vida", onde deve florescer a ação comunicativa. Gorz assinala tais semelhanças, embora cri- tique o conceito habermasiano de mundo-da-vida, que designa

[...] não, de fato, o mundo da experiência vivida original, mas o do vivido mediado pelos meios sociais de sua expressão formalizada, em particular pelos estereótipos da linguagem, e despojada de sua negatividade (Gorz, 1988, pp. 217-218).

Tal diferença é importante "numa situação em que não se trata de reproduzir a sociedade, mas de concebê-la em nova base e nova perspectiva" (Idem, p. 213). Mas, ainda assim, permanece uma concordância essencial entre Gorz e o Habermas da fase crítica. Para ambos, a deturpação essencial da vida moderna é a transferência de critérios próprios à esfera heterônoma para a esfera autônoma - a "colonização do mundo-davida pela razão instrumental”, no jargão habermasiano; a instrumentalização das atividades gratuitas pela racionalidade econômica, segundo Gorz.

Entendida como uma possibilidade histórica, a sociedade dual precisa sobrepor-se a outras possibilidades igualmente presentes. Gorz identifica uma saída conservadora para a crise da sociedade do trabalho, que passa pela ampliação da hegemonia da razão instrumental (ou "racionalidade econômica", em seus termos) em todos os espaços da vida humana. Os empregos estáveis de tempo integral tornam-se privilégio de uma elite de trabalhadores bem-pagos. À sua volta, uma periferia de subempregados executa os serviços subalternos. A borda externa dessa periferia inclui marginalizados permanentes, mantidos por mecanismos do Estado de bem-estar, como o seguro social.

Até aqui, a imagem é semelhante à do mercado de trabalho sob o regime de acumulação capitalista flexível, tal como apresentada, por exemplo, por David Harvey (1989, pp. 143-144). A esse quadro, Gorz acrescenta a expansão do campo das atividades assalariadas, proposta por economistas como solução para a crise de desemprego. Isso inclui, numa ponta, o pagamento de salários às donas-decasa e às mães; na outra, a expansão do mercado de mães de aluguel, prostitutas, serviçais, gente que fica à disposição da elite empregada nas atividades produtivas (Gorz, 1988). Essa imagem é a de uma sociedade em que todo o avanço tecno- 
lógico não resulta em um segundo a mais de tempo livre para ninguém. A elite trabalha sem cessar para manter seu consumo suntuoso e seus serviçais. Estes estão presos à necessidade imperiosa de "ganhar a vida". E os desempregados, entregues à boa-vontade do Estado, não têm condições materiais de transformar o tempo de não-trabalho em tempo de autodeterminação.

A manutenção artificial de uma sociedade do trabalho também está ligada à difusão de uma ideologia de "mais é melhor", núcleo da própria racionalidade econômica (Idem, p. 154). ${ }^{8}$ Da mesma forma que produz para criar trabalho, o capitalismo contemporâneo passa a "produzir consumidores para suas mercadorias, necessidades que correspondam aos produtos de produção mais rentável" (Gorz, 1983, p. 50). Essa ideologia impregna os trabalhadores que, por isso, se mantêm acorrentados ao trabalho, mais horas do que o necessário, para consumir mais do que precisam ou mesmo podem. Esses trabalhadores transferem a racionalidade econômica para a esfera do tempo livre, do lazer, das atividades que deveriam utilizar outra racionalidade, que deveriam perseguir fins em si mesmos. Inverter essa direção, subordinar o setor heterônomo à atividade autodeterminada, é o objetivo da utopia dualista.

Fica evidente que os operários não podem ser os promotores da instauração de uma sociedade de tempo liberado. Ao menos nos países centrais, uma parcela cada vez menor da população encontra-se empregada em período integral na indústria de transformação. Os operários remanescentes, orgulhosos de sua posição, permanecem fiéis à ideologia do trabalho e não se identificam com o projeto de uma sociedade de tempo liberado (Idem, p. 78). A utopia proposta por Gorz encontraria ressonância no que ele chama de "não-classe dos não-trabalhadores": desempregados e semi-empregados que cumprem tarefas de ocasião, intercambiáveis e com vínculos empregatícios precários. O trabalho, para eles, não é um espaço de realização e sim "um tempo morto à margem da vida" (Gorz, 1980, p. 89). Mas a "nãoclasse" não está dotada de nenhuma missão teleológica similar à do proletariado. Ao mesmo tempo em que prega a transformação da sociedade, Gorz confessa não saber "que forma pode tomar essa ação nem que força política é capaz de conduzi- la" (Idem, p. 22). A noção de "não-classe dos nãotrabalhadores", avançada provocativamente em Adeus ao proletariado, é abandonada nas obras posteriores. ${ }^{9}$

Além da ausência de um sujeito coletivo capaz de encampar o projeto, existem problemas no próprio funcionamento da sociedade projetada. O mais importante deles diz respeito à existência de toda uma gama de serviços socialmente úteis, embora não estritamente produtivos, que consomem muita mão-de-obra, como ocorre nas áreas de saúde e educação. A solução é a criação de mais uma esfera de trabalho, "comunitária" (Gorz, 1983, p. 126) - um terceiro setor, dito intermediário, para a utopia dualista. O cumprimento de tarefas na esfera comunitária não seria obrigatório, como no setor heterônomo. Haveria um incentivo: quem participasse do setor intermediário ganharia o direito de receber bens ou serviços numa quantidade equivalente às horas trabalhadas.

Essa solução, na verdade, expande o espaço do trabalho heterodeterminado, alienado, que não é um fim em si mesmo. O objetivo seria externo à tarefa: a obtenção dos bens e serviços trocáveis pelas horas despendidas. Por isso, Gorz acaba reduzindo sua idéia de setor intermediário ou comunitário à posição de "segunda melhor opção". A plena realização da utopia exige que essas atividades sejam assumidas pelo setor autônomo. Professores, médicos e profissionais semelhantes, bem como artistas e cientistas, encontrariam - como hoje, em certa medida, já encontram - no cumprimento de suas tarefas uma satisfação que independe da recompensa monetária. É a satisfação proporcionada pelo reconhecimento do discípulo, do paciente ou do público. A universalização dessas relações exige uma generosidade recíproca alheia à racionalidade econômica hoje hegemônica (Gorz, 1988).

Mas Gorz também procura mostrar que trabalhos especializados como o do médico, do jornalista ou do professor não exigem dedicação permanente. Esta seria uma idéia difundida pela elite dos especialistas bem-pagos, desejosos de manter seu monopólio sobre fatias do mercado de trabalho. Portanto, esses especialistas devem obter tempo para desenvolver outras atividades e, inversamente, suas especialidades devem ficar ao alcance de qualquer indivíduo desejoso de encontrar nelas alguns de seus caminhos para a 
auto-realização. Não se trata de eliminar a especialização necessária ao cumprimento de tarefas complexas, mas de democratizar o acesso a esses saberes (Gorz, 1983, p. 77).

A utopia dualista de Gorz mantém, assim, um compromisso essencial com a concepção marxista da auto-realização humana, que ocorre por intermédio do trabalho (entendido em oposição ao consumo):

A exigência de "trabalhar menos" não tem por sentido e por finalidade "descansar mais", mas "viver mais", o que quer dizer: poder realizar por si mesmo muitas coisas que o dinheiro não pode comprar e mesmo uma parte das coisas que ele atualmente compra (Gorz, 1980, p. 11).

Também como Marx, Gorz aposta no surgimento de um novo homem, capaz de usufruir as possibilidades que lhe são abertas pelo campo da atividade autônoma. Esse surgimento seria possibilitado pela limitação da racionalidade econômica à sua esfera própria. $O$ não-surgimento desse novo homem acabaria por transformar a utopia dualista em algo semelhante à sociedade do trabalho alienado atual - pela via da esfera intermediária de trabalho "comunitário" monetarizado. Neste caso, o triunfo da racionalidade econômica ocorreria sem constrangimentos sistêmicos, por escolha dos indivíduos. Eles usariam a liberdade conquistada para optar livremente pela servidão. Essa eventualidade pode ser descartada a priori apenas na medida em que se tenha a visão de uma "natureza humana" que, uma vez liberada dos constrangimentos atuais, ansiaria por oportunidades de pleno desenvolvimento de suas potencialidades criativas. Tal é a visão que, malgrado as críticas reiteradas à noção de "natureza humana", subjaz à percepção de Gorz, como de Marx, sobre a auto-realização das mulheres e dos homens.

\section{Renda para todos}

De todas as propostas analisadas aqui, a renda básica incondicional (ou "salário cidadão") é a que encontra maior receptividade entre inte- lectuais e políticos, sobretudo nos países da Europa ocidental. É necessário, em primeiro lugar, diferenciá-lo de outras políticas de transferência direta de renda do Estado para os cidadãos. Os projetos de "imposto negativo", patrocinados por ultraliberais como Milton Friedman, visam a substituir os serviços prestados pelo Estado (educação e saúde públicas, por exemplo) por uma quantia em dinheiro entregue àqueles com menor renda. O seguro-desemprego é um auxílio presumivelmente temporário para quem se encontra sem trabalho, pensado ainda dentro da lógica de um ideal de pleno emprego. Medidas como bolsa-escola ou renda mínima, defendidas no Brasil por líderes políticos como (respectivamente) os senadores Cristovam Buarque e Eduardo Suplicy, são paliativos destinados aos mais pobres, em alguns casos objetivando assegurar-lhes condições para a inserção no mercado de trabalho. O "segundo cheque" de Guy Aznar, que será discutido adiante com um pouco mais de detalhe, busca a redução da jornada de trabalho daqueles que estão empregados.

A renda básica incondicional ou universal, por sua vez, é aquilo que seu nome indica - uma transferência de renda permanente do Estado para todo e qualquer cidadão, independentemente de suas características pessoais, de possuir ou não outras fontes de renda, de estar ou não disposto a aceitar um emprego, caso tenha esta possibilidade. Todos recebem pelo simples fato de serem cidadãos. A renda básica incondicional se estabelece como alternativa tanto à utopia esboçada por Gorz como à saída conservadora para a crise da sociedade do trabalho.

Seu objetivo é libertar as pessoas da imposição do trabalho assalariado - ou devido a uma postura filosófica, ou por se considerar, como Offe, Mückenberger e Ostner (1996 [1989], pp. 208-209), que tentativas de retorno ao pleno emprego são ilusórias, economicamente indesejáveis e ecologicamente nefastas. Embora compartilhe do objetivo, Gorz mostrou-se avesso à alternativa, recusando o desenho de sociedade que ela projetava. Na base desta rejeição, estava seu entendimento de que a participação na atividade produtiva funda o direito de cidadania.

De forma algo bombástica, o principal difusor da renda básica universal, o filósofo belga Philippe Van Parijs, secretário do Basic Income 
European Network (BIEN), afirma que a proposta pode realizar o "velho ideal emancipatório associado ao movimento comunista, sem exigir para tanto nada semelhante a um modo socialista de produção" (Van Parijs, 1992, p. 466) - ou, então, que seria "uma via capitalista para o comunismo" (Van Der Veen e Van Parijs, 1987). O salário cidadão aboliria o jugo da necessidade, já que ninguém mais seria obrigado ao trabalho para suprir sua subsistência - na medida do desenvolvimento econômico, estaria garantido até mesmo o conforto, já que a idéia é oferecer aos cidadãos a "maior renda possível". Quem desejasse, porém, poderia buscar um emprego, trocando parte de seu tempo livre por maiores possibilidades de consumo. A organização capitalista ou socialista da economia é, a princípio, indiferente, embora Van Parijs julgue que, por motivos práticos, seria capitalista. Nenhum dos países de economia estatizada remanescentes no final do século XX possuía um grau de desenvolvimento suficiente para tentar implementar um tal projeto.

O caráter universal da renda básica impede que seus beneficiários sejam estigmatizados, como ocorre com os recebedores de seguro-desemprego, ou que se tornem presas do clientelismo político. Também garante o respeito à privacidade e às liberdades civis de todos, ao passo que muitos programas sociais hoje existentes envolvem o monitoramento dos favorecidos, para garantir que eles atendam aos critérios de elegibilidade para o programa, quando não os obrigam a cumprir alguns deveres (Van Parijs, 1997 [1991], p. 178). Assim, beneficiários do seguro-desemprego são vigiados para que não exerçam atividade remunerada ou, então, não podem recusar qualquer oferta de trabalho que lhes seja feita; famílias que recebem bolsa-escola devem provar que seus filhos não faltam às aulas; agentes do governo verificam as condições de pobreza dos candidatos aos programas assistenciais.

Não se trata, portanto, de um programa compensatório, destinado a garantir condições de vida aos "excluídos" ou a resolver a crise da oferta de emprego. É a busca da ampliação da liberdade efetiva de todos os cidadãos, incluindo a liberdade de não ganhar o pão com o suor do rosto, hoje desfrutada apenas por alguns poucos rentistas ou herdeiros. Nesse sentido, se distancia de projetos de garantia de emprego, pelo qual o
Estado assumiria a responsabilidade de oferecer trabalho e salário a todos os que necessitassem (Mitchell e Watts, 2004). Ao contrário do que afirmam mesmo alguns de seus defensores (Noguera, 2001), a renda básica não seria apenas mais exeqüível e facilmente aplicável do que a garantia de emprego. Na perspectiva de Van Parijs, ela apresenta um ideal superior, passando do direito ao trabalho para o direito ao não-trabalho.

De início, a renda básica universal poderia até ser inferior ao montante socialmente considerado necessário para uma vida digna (Van Parijs, 1992, p. 472). No entanto, é possível objetar que, neste caso, o projeto não atingiria seus fins. As pessoas continuariam constrangidas a procurar emprego assalariado e a alocação universal de renda serviria apenas para reduzir o custo da mão-de-obra, beneficiando o capital, mas não os trabalhadores. Apenas quando atinge o limiar do "mínimo necessário" o salário-cidadão cumpre a função de fortalecer os (possíveis) assalariados, que estão em melhor posição de barganha, já que passam a ter a opção de não aceitar nenhum emprego. A partir daí, quanto mais alta a alocação de renda, maior o poder de negociação dos trabalhadores.

Apesar do que afirma Van Parijs, é difícil vislumbrar a convivência, a longo prazo, desse modelo com o capitalismo. Um dos traços fundamentais da ordem capitalista é a desigualdade estrutural que força os não-possuidores de meios de produção a venderem sua força de trabalho ao capital, premidos pela necessidade de subsistência e pela existência do exército industrial de reserva. A renda básica vive, então, um dilema, pois, quando está abaixo do nível de subsistência, funciona "como um subsídio para empregadores pagando baixos salários", e se sobe acima da subsistência "rompe o funcionamento da economia capitalista" e passa a enfrentar a oposição feroz dos interesses contrariados (Callinicos, 2000, p. 118). A avaliação da força da oposição da burguesia é essencial para considerar as dificuldades de implementação do projeto - se é uma mera questão tributária (qual o nível de imposto necessário para a concessão de renda básica a todos em determinado patamar, um problema técnico do qual Van Parijs e outros se ocupam bastante, mas que aqui não interessa) ou praticamente uma desapropriação. 
Cumpre observar ainda que o modelo exige que uma determinada quantidade de pessoas aceite os incentivos para se integrarem ao trabalho produtivo e, assim, gerar a riqueza necessária para sustentar a renda universal de todos. Isto significa a manutenção do padrão aquisitivo que caracteriza os homens e as mulheres das sociedades capitalistas. Por outro lado, há a preocupação de defender a legitimidade ética da opção por não trabalhar, em termos do respeito liberal às diferentes concepções do que é a boa vida. Aqueles que decidem permanecer apenas com o saláriocidadão não são parasitas que vivem às custas da riqueza produzida por outros, mas indivíduos que, ao perseguirem sua própria concepção do bem que valoriza o tempo livre, acima do consumo ou do conforto material -, permitem que outros, com concepções de bem diversas, se assenhorem dos postos de trabalho existentes (Van Parijs, 1991).

Numa veia diversa, o sociólogo polonês Zygmunt Bauman apresentou uma defesa da renda básica universal em termos de suas conseqüências políticas. Ela reduziria a incerteza existencial que, hoje, mina o espaço público e "reintroduziria padrões morais na vida social, substituindo o princípio da competição pelo da participação" (Bauman, 2000 [1999], p. 186). ${ }^{10}$ No momento em que o Estado se compromete a garantir a todos os cidadãos o necessário para sua sobrevivência digna, ele reassume seu papel de promotor do bem comum. Ao que parece, Bauman julga que, assegurado o provimento de suas necessidades, as pessoas vão, como que automaticamente, ampliar a participação política. Para sustentar tal conclusão, ele afirma que "o direito universal à renda vai baixar as apostas no jogo do consumo, uma vez que entrar nele não será mais uma questão de sobrevivência" (Idem, p. 190). A idéia de que a sociedade de consumo é fundada na busca de sobrevivência de suas vítimas, porém, soa bizarra e não é explicada pelo autor.

Gorz criticou duramente a proposta de renda básica, encarando suas conseqüências políticas de forma oposta à de Bauman. Ela contribuiria para a atomização dos indivíduos, eliminando o espaço público associado às atividades econômicas, sem apresentar outro em troca (Gorz, 1991, p. 174). Mais importante ainda, de seu ponto de vista, era a objeção moral. A alocação universal "permite à sociedade não se ocupar da repartição eqüitativa do fardo" do trabalho (Idem, p. 176). A sociedade seria cortada em dois, alguns permanecendo vinculados a um ethos aquisitivo, buscando maior retribuição monetária e, assim, maiores possibilidade de consumo, e outros se eximindo de dar sua contribuição para o bem-estar coletivo.

Embora pudesse até eliminar a condenação da maioria da população ao assalariamento, a renda básica permaneceria compatível com a monetarização das relações sociais e não contribuiria para a geração de uma nova solidariedade, que superasse o individualismo egoísta das sociedades capitalistas. Excluídos pela sociedade, que os condena à marginalidade, os beneficiários do rendimento universal receberiam do Estado um auxílio destinando a garantir sua subsistência, sem reinseri-los no tecido social. Em suma, o projeto desempenharia um papel conservador, visando apenas a "tornar socialmente suportável a dominação [da racionalidade econômical sobre a sociedade" (Gorz, 1988, p. 165) e negando a uma parcela da população o "direito de acesso à esfera econômica pública por meio do próprio trabalho [que] é indissociável do direito à cidadania" (Idem, p. 175).

Aceitável, no máximo, como medida de transição, enquanto o trabalho é redistribuído, a medida reaparece de forma bem diferente na figura do "segundo cheque", a proposta de Guy Aznar (1995 [1993]) endossada por Gorz. Trata-se de uma compensação social, que recompõe a renda caso a redução da jornada implique em redução do salário. Mas, ao contrário da renda básica universal, o rendimento concedido pelo Estado não está desvinculado da participação de todos na esfera pública do trabalho. Trata-se de um incentivo para a redução da jornada nas empresas, de forma que mais pessoas participem da produção; "seu objetivo não é a distribuição de renda, mas a distribuição de trabalho" (Silva, 2002, p. 191).

Em sua obra mais recente, porém, Gorz recuou desta posição. Ele passou a admitir que os projetos de renda básica universal são politicamente mais viáveis; ao mesmo tempo, reconheceu que a realidade das economias contemporâneas, "pós-fordistas", impõe graves obstáculos ao cálculo do tempo de trabalho, necessário em seu esquema anterior. Embora sejam acrescentadas certas condições para a boa implementação de uma política de alocação incondicional de renda, 
incluindo a busca de novas formas de cooperação e de sociabilidade, tal mudança representa um sério aviltamento - em nome do "realismo" - do projeto utópico desenvolvido nos escritores anteriores, fato do qual, aliás, o autor demonstra estar consciente (Gorz, 1997, pp. 130-156). ${ }^{11}$

Como visto, a desvinculação entre o trabalho e o direito à subsistência, que está no cerne da proposta de renda básica incondicional, ampliaria de forma substantiva a capacidade que a maioria das pessoas tem de decidir como deseja tocar a própria vida, isto é, "a liberdade real de levar a própria vida da forma como se desejar" (Van Parijs, 1992, p. 470). Mas tal liberdade é entendida como pertencendo exclusivamente à esfera priva$\mathrm{da}$, sem que sejam previstas medidas de ampliação da autonomia coletiva no Estado ou na gestão da economia.

Da mesma forma que o modelo de Gorz, a renda básica universal pressupõe uma sociedade altamente industrializada, com elevadíssima produtividade, de modo que o trabalho de alguns seja suficiente para suprir as necessidades de todos. Para o resto do mundo, parece que a única alternativa é trilhar o mesmo caminho dos países capitalistas desenvolvidos e, lá chegando, adotar seu próprio sistema de renda incondicional. Por vezes, os autores que defendem a proposta apresentam um reconhecimento protocolar dos problemas da justiça internacional, apenas para afirmar que eles não serão abordados (Van Parijs, 1991, p. 102). No entanto, trata-se de uma questão importante, ainda que se deixe de lado a idéia de imperialismo, isto é, a investigação sobre o papel da transferência de riquezas dos países pobres na prosperidade do chamado "primeiro mundo".

Um dos mais graves problemas enfrentados nos países para os quais a proposta de renda básica se dirige é a presença de um vasto contingente de imigrantes de países pobres, que não são admitidos à cidadania, estão submetidos a condições precárias de vida e tornam-se o bode expiatório do discurso xenófobo da extrema-direita. Uma política de salário-cidadão não pode acolhê-los, pois pressionariam em excesso os recursos disponíveis - ainda que admita os atuais residentes, não teria como absorver novas levas de imigrantes, seguramente ainda mais numerosas, pois atraídas pela própria existência da renda incondicional.
Restam duas alternativas: um extremo rigor policial, para impedir a entrada e permanência de estrangeiros, ou um sistema com duas castas, no qual os estrangeiros não receberiam o benefício da renda básica e continuariam dependentes da venda da sua força de trabalho para sobreviver. No primeiro caso, a utopia tomaria a estranha forma de uma sociedade de vigilância permanente, com um aparato repressivo alargado. (Não custa observar que, nas condições de liberdade da obrigação de trabalhar que o modelo produz, a manutenção de tal aparato seria extremamente dispendiosa.) No segundo caso, há a geração de uma profunda desigualdade social, um verdadeiro apartheid entre cidadãos e imigrantes. E a simples presença dos trabalhadores estrangeiros, ainda constrangidos pelo aguilhão da necessidade, anularia um dos benefícios esperados, o fortalecimento da posição dos vendedores de mão-de-obra vis-à-vis o capital.

\section{A loteria total}

A proposta utópica mais radical, que implica na transformação mais extensa da ordem social, é a de Barbara Goodwin. Ela consiste em fazer dos sorteios o meio universal de alocação de recursos escassos, a começar pelas posições de poder e prestígio. O apelo ao acaso é, em geral, considerado uma confissão da falência no uso da razão. No entanto, a escolha aleatória é um método útil em situações nas quais os custos da decisão são demasiado elevados ou ninguém quer arcar com a responsabilidade moral por ela (Elster, 1991 [1988]). As loterias são igualitárias, imunes à corrupção e evitam o conflito sobre critérios de merecimento (Elster, 1992, p. 72). Nas últimas décadas, diversos pensadores têm proposto a adoção de sorteios como forma de combater os vícios encontrados na seleção eleitoral dos representantes políticos (Miguel, 2000).

A proposta de Goodwin é bem mais ousada do que o mero sorteio de legisladores. Seu elemento básico é o entendimento radical de que nossas vidas são em grande medida condicionadas por um acaso inicial, a "loteria do nascimento". Ela determina nossas características genéticas e, muito mais importante, a posição de onde partimos na sociedade, que faz com que herdemos 
não apenas bens, mas status, formação cultural, títulos e contatos com outras pessoas. A família é o mais renitente instrumento de perpetuação de desigualdades sociais, justamente por desempenhar múltiplas funções - afetivas, econômicas, educacionais e outras -, o que faz com que sugestões para que seja abolida, à la Platão, em geral pareçam muito pouco atraentes.

Se não é possível eliminar a loteria do nascimento, então o caminho é reduzir ao máximo a sua influência. Ela deixa de ser "a" loteria, aquela que define de uma vez por todas as possibilidades de cada um no espaço social, para se tornar apenas a primeira de uma longa série. A inspiração de Goodwin é "La lotería en Babilonia", um conto de Borges (1974 [1944]), que ela lê, com exagero, como uma sátira ao capitalismo, denunciando que as hierarquias sociais não refletem mérito ou escolhas, mas apenas o acaso (Goodwin, 1992, p. 28). No conto, insatisfeitos com o método convencional de premiação das loterias, os babilônios adotam um modelo mais emocionante, em que passam a ser sorteadas também punições. Ao final, toda a ordem social está dependente dos resultados lotéricos.

À maneira das narrativas utópicas renascentistas, Goodwin abre seu livro com a descrição de Aleatoria, sociedade imaginária na qual tudo é decidido pela sorte, do recrutamento das forças policiais ao número de filhos de cada mulher, de quem serão os magistrados à casa em que cada um vai residir. Nos capítulos seguintes, analisa os pontos fortes e fracos do projeto, avaliando potencialidades e limites da introdução da loteria como mecanismo de distribuição de bens e posições nos diversos campos sociais.

A sociedade lotérica representa uma tentativa de combinação entre os valores da diversidade e da igualdade. Os projetos socialistas tendem, muitas vezes, a uma equalização excessiva das condições de existência, o que, na concepção de Goodwin, representa uma perda. A convivência com uma multiplicidade de modos de vida é um valor em si mesma e deve ser preservada; como ela depende da diferença não apenas cultural, mas também de recursos materiais, implica na manutenção de um grau razoavelmente elevado de desigualdade econômica.

Para garantir que o caráter igualitário da utopia vingará, Goodwin imagina três mecanismos principais. Primeiro, a dissociação entre as diversas vantagens de cada posição no espaço social. Uma das peculiaridades mais perversas do mundo em que vivemos é que os desprivilegiados e os privilegiados tendem a se manter como tal em todas as dimensões. Os trabalhos mais gratificantes são em geral aqueles com maior prestígio social e com melhores salários; portanto, seus ocupantes costumam morar em casas maiores e mais cômodas, que são também mais bem localizadas; os ocupantes destas casas melhores possuem mais itens de conforto e consomem produtos de melhor qualidade, têm mais acesso ao lazer e à cultura e viajam com mais freqüência. A lista de vantagens cumulativas é quase interminável. O projeto de Goodwin separa trabalho de renda (e, portanto, de consumo) e também de moradia. Os diferentes empregos - estimulantes ou enfadonhos, satisfatórios ou desgastantes - serão distribuídos de forma aleatória e os diferentes salários também, mas em sorteios independentes. O mesmo vale para as habitações.

O segundo mecanismo é a rotatividade. As diferentes posições serão redistribuídas periodicamente, o que garante que a diversidade de modos de vida não será experimentada apenas ao nível social, mas também pessoal. Embora, num determinado momento, A esteja em situação inferior a B, em termos de status ou renda, em seguida as posições podem se inverter. A rotação é caracterizada como sendo o método justo de distribuição para bens indivisiveis de uso exclusivo (Goodwin, 1992, p. 58), como é o caso dos bons empregos e das boas moradias. (A renda poderia sofrer divisão eqüitativa, mas feriria a diversidade procurada e enfraqueceria o primeiro mecanismo compensatório.)

O terceiro mecanismo, enfim, é a limitação da aleatoriedade. Não será possível que a sorte (ou o azar) perpetue alguém numa posição; afinal, o objetivo é fazer com que cada pessoa experimente diferentes tipos de trabalho e de modos de vida, recebendo uma parcela equilibrada das vantagens e desvantagens (Idem, p. 9). O resultado é uma espécie de "aleatoriedade vigiada". Embora a autora critique Rawls por postular implicitamente que todos os participantes de sua "posição original" teriam aversão ao risco, evitando produzir uma sociedade injusta por temor de ficar no pólo negativo da injustiça (Idem, p. 32), este mecanis- 
mo reduz de forma brutal as incertezas existentes em sua utopia lotérica.

Embora o ponto não seja discutido por Goodwin, a implementação de sua utopia exige a estatização dos meios de produção - ainda que alguns possam ficar na posição de rentistas e outros, de administradores de empresas, as posições devem estar disponíveis para outros no momento do sorteio seguinte. Além dos proprietários, a proposta enfrentaria a oposição dos detentores do poder políticos, assalariados com alta renda, ocupantes dos melhores empregos, enfim, de todos aqueles que de alguma maneira se encontram em posições de elite. A autora está consciente do fato, mas evita qualquer discussão sobre a transição.

Os dois principais problemas da sociedade lotérica são identificados com facilidade. O primeiro diz respeito às ocupações especializadas (algo que também afeta, embora em menor medida, a utopia de Gorz). Seria razoável preencher por sorteio funções delicadas e que exigem anos de preparo prévio, como, digamos, as de engenheiro nuclear ou neurocirurgião?

Em favor da proposta de Goodwin, é necessário dizer que, por mais vistosas que sejam, tais profissões ocupam uma parcela bastante minoritária da população economicamente ativa. Os postos de trabalho mais numerosos exigem relativamente pouca qualificação - trabalhos braçais, empregos de escritório e assemelhados. No entanto, são em geral as ocupações mais especializadas que atraem a imaginação das pessoas e conferem charme à alternativa lotérica. Pouca gente se entusiasmaria com a possibilidade de experimentar posições sucessivas de pedreiro, motorista, bancário, porteiro e faxineiro, sonhando antes em ser cosmonauta, médico, piloto de avião, violoncelista ou trapezista.

Por um lado, é possível argumentar que, da mesma forma que atividades hoje corriqueiras foram no passado exclusivas de especialistas (ler e escrever, dominar uma língua estrangeira, usar o computador), podemos banalizar várias competências que ainda se mantêm exclusivas, muitas vezes por pressão de profissionais desejosos de manter seus privilégios - um ponto que é desenvolvido por Gorz (1988, pp. 101-102). Por outro, a sociedade deve estar adaptada à polivalência de seus integrantes. Por exemplo, um sistema legal simplificado facilita o trabalho de juízes e advogados selecionados por sorteio (Goodwin, 1992, p. 8). Mas restam muitos casos que não são passíveis de resolução nem pela disseminação dos saberes necessários, nem pela redução da complexidade das tarefas. Para estes, o que se aponta é uma solução intermediária: os profissionais também executarão, eventualmente, trabalhos não-especializados (Idem, p. 11).

Fica claro que a utopia é projetada para uma sociedade extremamente próspera, capaz tanto de prover os múltiplos treinamentos necessários para que cada indivíduo exerça suas atividades sucessivas, como de dispensar o trabalho de profissionais com alta qualificação. Mesmo no caso de profissões menos especializadas, o custo da anulação sistemática da experiência acumulada pode ser significativo. O desperdício de recursos humanos é alto, bem como o risco de incompetência no exercício das diversas funções - este último, agravado pela inexistência de grupos com continuidade significativa em qualquer campo de atividade. ${ }^{12}$

O segundo grande problema da utopia lotérica é a ausência de liberdade individual. Mesmo deixando de lado as medidas mais extremas como a imposição do número de filhos por mulher -, a ausência da possibilidade de escolher uma carreira ou o local de moradia reduz, de forma muito significativa, a capacidade que cada pessoa tem de escolher o rumo da própria vida (ou, para usar a linguagem da filosofia política, de perseguir sua própria concepção de bem). A resposta à crítica passa pela negação da possibilidade de liberdade real, com uma radicalização da denúncia (marxista, mas não só) da vacuidade das liberdades formais sob as condições da sociedade capitalista.

O que limita a liberdade é a escassez, o fato de que, para darmos curso às nossas escolhas, precisamos de meios de que muitas vezes não podemos dispor. Hoje, a escassez é "resolvida" pelo mercado, isto é, em prejuízo sistemático dos mais pobres e dos mais frágeis (Idem, p. 178). Para estes, a liberdade de controlar a própria vida é uma quimera. De maneira esquemática, é razoável dizer que o comunismo marxista imaginava a completa superação da escassez (e, portanto, a liberdade total para todos). O igualitarismo socialista distribui riqueza e escassez entre todos, em parcelas idênticas, gerando uma sociedade com baixa diversida- 
de. Descrente na abundância absoluta vislumbrada por Marx e descontente com a mediocridade que detecta no socialismo, a utopia lotérica descarta a liberdade individual como valor, por irrealizável. Em seu lugar, deseja dar a cada um e a cada uma oportunidades para seguir variados caminhos, em vez de ter uma única trajetória de vida, determinada pela loteria do nascimento.

\section{Conclusão}

A exposição evidenciou que as cinco propostas utópicas aqui discutidas são bastante diferenciadas quanto ao estatuto político que possuem. O projeto de Barbara Goodwin é uma provocação intelectual, sem intenção de se tornar uma diretriz para a ação política, destinada a revelar as perversidades da ordem liberal. Em sentido oposto (e com maior repercussão), o anarcocapitalismo cumpre função similar. Longe de ser um modelo que almeja ser implementado, é um reforço ideológico para a equação que iguala o mercado à liberdade e o Estado, à opressão. Numa curiosa transformação, quando se lembra das denúncias contra o "comitê gestor dos interesses da burguesia", no século XIX e primeira metade do século XX, são as propostas vinculadas ao ideário histórico da esquerda que exigem um aparelho estatal consideravelmente fortalecido, capaz de reger toda a organização social.

Já o projeto de renda básica universal, desenvolvido em grande detalhe e com diversas simulações por redes de pesquisadores e ativistas como o BIEN de Phillipe Van Parijs, ${ }^{13}$ é uma plataforma atuante no ambiente europeu ocidental, impondo-se como uma alternativa a ser levada a sério no campo político. As utopias de Gorz e, ainda mais, de Roemer não conseguiram alcançar tal patamar, embora aspirassem a isso.

O Quadro 1 sintetiza as principais características dos cinco modelos utópicos estudados. O de Gorz destaca-se pela aposta na redução do espaço das relações instrumentais entre as pessoas, valorizando a convivencialidade mais solidária, apreciada por si mesma e "desinteressada". Uma preocupação similar pode ser vislumbrada no projeto de renda básica universal, mas apenas de forma tênue, e está ausente por completo nos outros.
A solidariedade presente na proposta de Van Parijs é "fria", mediada pelo aparato estatal, realizando-se na transferência de riqueza que permite a alguns dispensarem uma obrigação de trabalhar que encaram como um fardo. Não há a aposta em - e o estímulo a - trocas diretas generosas entre os integrantes da sociedade, como ocorre na utopia dualista. Nesse sentido, o modelo apresentado por Gorz implica um desafio muito mais elevado, na busca pela construção de um mundo social diferente. Seu esforço tem como núcleo a redução ao mínimo possível do espaço destinado à operação dos mecanismos de mercado, entendidos como alienantes em si mesmos e opostos à interação humana solidária. Ele se contrapõe não apenas aos anarcocapitalistas, como é óbvio, mas também às outras propostas de esquerda, que mantêm as trocas mercantis, ainda quando as constrangendo severamente (como no caso de Goodwin).

Assim, Gorz e, em menor medida, Van Parijs encontram-se num pólo, em oposição ao qual estão os anarcocapitalistas e, com feições bem mais moderadas, Roemer. É a escala relativa à continuidade ou à transformação das motivações humanas dominantes nas sociedades atuais - questão que, em si, sempre foi crucial para o pensamento utópico. Goodwin mantém-se numa posição excêntrica; para ela, a questão das motivações é irrelevante, já que se trata de impelir todos a experimentarem uma diversidade de modos de vida.

Em todos os cinco modelos utópicos, os problemas sem resposta são grandes o suficiente para comprometer a realização dos benefícios esperados. Mas o mesmo pode ser dito das sociedades em que vivemos; suas promessas (de democracia, de liberdade, de segurança, de igualdade, de abundância, de paz) permanecem em larga medida não-cumpridas. Talvez seja exagerado dizer, como fez retoricamente um colaborador de Gorz, Gunnar Adler-Karlsson, que os problemas das propostas utópicas seriam solucionados se dessa tarefa se ocupasse "um centésimo do pessoal e dos economistas" que hoje se empenham na salvação da sociedade atual (apud Gorz, 1988, p. 262). Não resta dúvida, por outro lado, que os impasses existentes hoje dificilmente serão resolvidos no quadro institucional existente - o que não quer dizer que o "sistema" seja incapaz 
Quadro 1

Comparação entre os Modelos Utópicos

\begin{tabular}{|c|c|c|c|c|}
\hline MODELOS & \begin{tabular}{|c|} 
BEM A \\
SER DISTRIBUÍDO
\end{tabular} & MECANISMOS & $\begin{array}{l}\text { BENEFÍCIOS } \\
\text { ESPERADOS }\end{array}$ & Problemas \\
\hline $\begin{array}{l}\text { Anarcocapitalismo } \\
\text { (Friedman, } \\
\text { Rothbard) }\end{array}$ & Independência & $\begin{array}{l}\text { - Universalização das relações } \\
\text { de mercado. }\end{array}$ & $\begin{array}{l}\text { - Inexistência de } \\
\text { aparatos coercitivos } \\
\text { - Plena liberdade } \\
\text { individual. }\end{array}$ & $\begin{array}{l}\text { - Insegurança social. } \\
\text { - Exacerbação das } \\
\text { desigualdades. } \\
\text { - Penúria material reduz } \\
\text { capacidade de gozar dos } \\
\text { benefícios esperados. } \\
\text { - Defesa externa. }\end{array}$ \\
\hline $\begin{array}{l}\text { Renda básica } \\
\text { incondicional } \\
\text { (Van Pariijs) }\end{array}$ & Renda & $\begin{array}{l}\text { - Renda suficiente para uma } \\
\text { vida digna, distribuída a todos } \\
\text { os cidadãos. }\end{array}$ & $\begin{array}{l}\text { - Efetiva liberdade de } \\
\text { escolha (trabalhar ou } \\
\text { não trabalhar). }\end{array}$ & $\begin{array}{l}\text { - Necessidade de } \\
\text { manutenção de incentivos } \\
\text { materiais, sob risco de crise } \\
\text { de produção. } \\
\text { - Absorção ou contenção de } \\
\text { imigrantes. }\end{array}$ \\
\hline $\begin{array}{l}\text { Socialismo } \\
\text { de ações } \\
\text { (Roemer) }\end{array}$ & $\begin{array}{l}\text { Propriedade } \\
\text { dos meios } \\
\text { de produção }\end{array}$ & $\begin{array}{l}\text { - Duplo padrão monetário. } \\
\text { - Dissociação entre controle } \\
\text { do capital e riqueza material. } \\
\text { - Extinção do direito de } \\
\text { herança para o controle do } \\
\text { capital. }\end{array}$ & $\begin{array}{l}\text { - Efetiva igualdade de } \\
\text { oportunidades. } \\
\text { - Manutenção das } \\
\text { vantagens da economia } \\
\text { de mercado sem a } \\
\text { desigualdade que ela } \\
\text { produz. }\end{array}$ & $\begin{array}{l}\text { - Possível incompetência } \\
\text { dos investidores ou gestão } \\
\text { burocrática do mercado de } \\
\text { ações. } \\
\text { - Possibilidade de crise de } \\
\text { desinvestimento devido à } \\
\text { impossibilidade de herdar o } \\
\text { capital. } \\
\text { - Permanência da } \\
\text { alienação no trabalho. }\end{array}$ \\
\hline $\begin{array}{l}\text { Sociedade } \\
\text { dual } \\
\text { (Gorz) }\end{array}$ & Tempo livre & $\begin{array}{l}\text { - Alocação eqüitativa do } \\
\text { trabalho socialmente } \\
\text { necessário. } \\
\text { - Economia "dual", com } \\
\text { setores heterônomo e } \\
\text { autônomo. }\end{array}$ & $\begin{array}{l}\text { - Possibilidade de } \\
\text { desenvolvimento pleno } \\
\text { das capacidades } \\
\text { individuais, graças ao } \\
\text { trânsito entre múltiplas } \\
\text { ocupações. } \\
\text { - Justa distribuição dos } \\
\text { encargos sociais. } \\
\text { - Redução das relações } \\
\text { pessoais mediadas pela } \\
\text { moeda. }\end{array}$ & $\begin{array}{l}\text { - } 0 \text { modelo não lida a } \\
\text { contento com as tarefas que } \\
\text { consomem mão-de-obra de } \\
\text { forma intensiva (educação, } \\
\text { saúde). } \\
\text { - Perda de eficiência e } \\
\text { desperdício de recursos } \\
\text { humanos decorrente da } \\
\text { ausência de especialização. } \\
\text { - Absorção ou contenção de } \\
\text { imigrantes. }\end{array}$ \\
\hline $\begin{array}{l}\text { Sociedade } \\
\text { lotérica } \\
\text { (Goodwin) }\end{array}$ & Chance & $\begin{array}{l}\text { - Alocação de bens sociais por } \\
\text { sorteios. } \\
\text { - Dissociação entre renda, } \\
\text { status e conforto. }\end{array}$ & $\begin{array}{l}\text { - Multiplicação das } \\
\text { experiências } \\
\text { individuais. } \\
\text { - Combinação de } \\
\text { efetiva igualdade com } \\
\text { diversidade social. }\end{array}$ & $\begin{array}{l}\text { - Autoritarismo. } \\
\text { - Incerteza extrema. } \\
\text { - Perda de eficiência e } \\
\text { desperdício de recursos } \\
\text { humanos decorrente da } \\
\text { ausência de especialização. }\end{array}$ \\
\hline
\end{tabular}

de se reproduzir por um período indeterminado, e sim que ele é cada vez mais incapaz de realizar os valores que abraça ostensivamente.
Ao criticar o mundo presente e mostrar que outras opções são possíveis - ainda que com lacunas -, o pensamento utópico cumpre o seu papel, 
espanando a acomodação diante de conceitos, categorias e formas de reflexão dominantes. Mais do que legitimar a ordem existente, o discurso da ideologia muitas vezes nega viabilidade a qualquer alternativa: faz com que pensemos que "o mundo é mesmo assim" e, por conseqüência, nos conformemos com o jeito que ele é. Por isso, o discurso anti-ideológico carrega necessariamente um componente utópico (como já dizia o velho Mannheim). Com suas limitações, com suas imperfeições, em muitos casos mesmo com sua falta de ousadia, as propostas de Roemer, Gorz, Van Parijs e Goodwin reafirmam este fato.

\section{BIBLIOGRAFIA}

ANDERSON, Perry. (1995), "Balanço do neoliberalismo", in Emir Sader e Pablo Gentili (orgs.), Pós-neoliberalismo: as políticas sociais e o Estado democrático, São Paulo, Paz e Terra.

AZNAR, Guy. (1995 [1993]), Trabalhar menos para trabalharem todos. São Paulo, Scritta.

BACZKO, Bronislaw. (1984), Les imaginaires sociaux: mémoires et espoirs collectifs. Paris, Payot.

BAUMAN, Zygmunt. (2000 [1999]), Em busca da política. Rio de Janeiro, Jorge Zahar.

BORGES, Jorge Luis. (1974 [1944]), "La lotería en Babilonia", in Obras completas, Buenos Aires, Emecé.

BORON, Atilio A. (1994 [1991]), "Mercado, Estado e democracia: reflexões em torno da teoria política do monetarismo", in Estado, capitalismo e democracia na América Latina, São Paulo, Paz e Terra.

BRIGHOUSE, Harry. (1996), "Transitional and utopian market socialism", in Erik Olin Wright (ed.), Equal shares: making market socialism work, Londres, Verso.

CALLINICOS, Alex. (2000), Equality. Cambridge, Polity.

DAHRENDORF, Ralf. (1991 [1990]), Reflexões sobre a revolução na Europa. Rio de Janeiro, Jorge Zahar.

ENGELS, Friedrich. (s.d. [1873]), "Sobre a autoridade", in Karl Marx e Friedrich Engels, Obras escolbidas, São Paulo, Alfa-Ômega, vol. 2.

ELSTER, Jon. (1992), Local justice: how institutions allocate scarce goods and necessary burdens. Nova York, Russell Sage.

(1991 [1998]), Domar la suerte: la aleatoriedad en decisiones individuales y sociales. Barcelona, Paidós.

FRASER, Nancy. (1997), Justice interruptus: critical reflections on the 'postsocialist' condition. Nova York, Routledge.

FRIEDMAN, David. (1989 [1973]), The machinery of freedom: guide to a radical capitalism. Chicago, Open Court.

FRIEDMAN, Milton. (1985 [1962]), Capitalismo e liberdade. São Paulo, Nova Cultural, 1985.

GOODWIN, Barbara. (1992), Justice by lottery. Chicago, The University of Chicago Press.

GORZ, André. (1983), Les chemins du paradis. Paris, Galilée.

(1987 [1980]), Adeus ao proletariado: para além do socialismo. Rio de Janeiro, Forense-Universitária, 1987.

(1988), Métamorphoses du travail: quête du sens. Critique de la raison économique. Paris, Galilée.

(1991), Capitalisme, socialisme, écologie: désorientations, orientations. Paris, Galilée.

(1997), Misères du présent, richesses du possible. Paris, Galilée.

(2003), L'immatériel: connaissance, valeur et capital. Paris, Galilée.

GRAMSCI, Antonio. (1976 [1929-1935]), Maquiavel, a política e o Estado moderno. Rio de Janeiro, Civilização Brasileira.

HARVEY, David. (1992 [1989]), A condição pósmoderna: uma pesquisa sobre as origens da mudança cultural. São Paulo, Loyola.

HAYEK, F. A. (1990 [1944]), O caminho da servi- 
dão. Rio de Janeiro, Instituto Liberal.

MACPHERSON, C. B. (1962), The political theory of possessive individualism: Hobbes to Locke. Oxford, Oxford University Press.

MARX, Karl. (1976 [1848]), "Le Débat Social sur l'Association Démocratique", in Karl Marx e Friedrich Engels, Utopisme \& communauté de l'avenir, Paris, Maspero.

(1988 [1861-1879]), El capital. México, Siglo Veintiuno.

MÉSZAROS, István. (2002 [1995]), Para além do capital: rumo a uma teoria da transição. Campinas/São Paulo, Editora da Unicamp/Boitempo.

MIGUEL, Luis Felipe. (1999a), "Thomas More e o nascimento do pensamento político moderno". Boletim, 37: 53-71, Londrina.

(1999b), "Liberdade ou felicidade? A auto-realização humana em Marx, Gorz e Elster". Revista de Filosofia Política, 4: 176-210 (nova série), Porto Alegre.

. (2000), "Sorteios e representação democrática". Lua Nova, 50: 69-96, São Paulo.

MILIBAND, Ralph. (2000 [1994]), Socialismo e ceticismo. São Paulo/Bauru, Editora da Unesp/Edusc.

MILL, John Stuart. (1991 [1859]), Sobre a liberdade. Petrópolis, Vozes.

MITCHELL, William \& WATTS, Martin. (2004), "A comparison of the macroeconomic consequences of basic income and job guarantee schemes". Working Papers, 4-5: 2-23, Callaghan, (Centre of Full Employment and Equity).

NOGUERA, José Antonio. (2001), “Renta básica o 'trabajo básico'? Algunos argumentos desde la teoría social". Paper apresentado no I Simposio sobre la Renta Básica (Barcelona).

NOVE, Alec. (1989 [1983]), A economia do socialismo possível. São Paulo, Ática.

NOZICK, Robert. (1991 [1974]), Anarquia, Estado e utopia. Rio de Janeiro, Jorge Zahar.
OFFE, Claus; MÜCKENBERGER, Ulrich \& OSTNER, Ilona. (1996 [1989]), "A basic income guaranteed by the State: a need of the moment in social policy", in Claus Offe, Modernity and the State: East, West, Cambridge, Polity.

PHILLIPS, Anne. (1999), Which equalities matter? Cambridge, Polity.

POPPER, Karl. (1974 [1945]), A sociedade aberta e seus inimigos, Belo Horizonte, Itatiaia; São Paulo, Edusp, 2 vols.

RAWLS, John. (1997 [1971]), Uma teoria da justiça. São Paulo, Martins Fontes.

(2000 [1993]), O liberalismo político. São Paulo, Ática.

RIKER, William H. (1982), Liberalism against populism: a confrontation between the theory of democracy and the theory of social choice. Prospect Heights, Waveland.

ROEMER, John E. (1994), A future for socialism. Cambridge (MA), Harvard University Press.

(1996), "A future for socialism", in Erik Olin Wright (ed.), Equal shares: making market socialism work, Londres, Verso.

ROTHBARD, Murray N. (1962), Man, economy, and State: a treatise on economic principles. Princeton, Van Nostrand.

(1970), Power and market: government and the economy. Menlo Park, Institute for Human Studies.

SANDEL, Michael. (1998), Liberalism and the limits of justice. $2^{\mathrm{a}}$ ed. Cambridge, Cambridge University Press.

SIMON, William H. (1996), "Inequality and alienation in the socialist capital market", in Erik Olin Wright (ed.), Equal shares: making market socialism work, Londres, Verso.

SILVA, Josué Pereira da. (2002), André Gorz: trabalho e politica. São Paulo, Annablume.

VAN DER VEEN, Robert J. \& VAN PARIJS, Phillipe. (1987), "A capitalist road to Communism". 
Theory and Society, 15 (5): 635-655, Dordrecht.

VAN PARIJS, Phillipe. (1991), "Why surfers should be fed: the liberal case for an unconditional basic income". Philosophy and Public Affairs, 20 (2): 101-131, Princeton.

(1992), "Basic income capitalism". Ethics, 102 (3): 465-484, Chicago.

(1997 [1991]), O que é uma sociedade justa? São Paulo, Ática.

(1998), "The disfranchisement of the elderly, and other attempts to secure intergenerational justice". Philosophy and Public Affairs, 27 (4): 292-333, Princeton.

WOOD, Ellen Meikisins. (1995), Democracy against capitalism: renewing historical materialism. Cambridge, Cambridge University Press.

WRIGHT, Erik Olin. (1996), "Political power, democracy and coupon socialism", in Erik Olin Wright (ed.), Equal shares: making market socialism work, Londres, Verso.

\section{Notas}

1 Uma observação terminológica: os anarcocapitalistas e outros fundamentalistas do mercado gostam de chamar a si mesmos de libertarians, termo que no Brasil vem sendo traduzido por "libertários" (ou então pelo neologismo "libertarianos"). Mas a palavra evoca uma tradição política diversa, dos anarquistas de esquerda, e contrabandeia a percepção ideológica de que as relações de mercado são, por definição, livres, com a opressão residindo no Estado. Por esses motivos, não será usada no texto.

2 É possível aventar a hipótese de que a maior atração que a utopia vem despertando na esquerda nas últimas décadas - basta lembrar do slogan do Fórum Social Mundial, "um outro mundo é possível”, de inegável sabor utopista - está ligada à falência de seus projetos históricos, motivando a esperança em alternativas aparentemente mais irrealistas.

3 Discuti a trajetória do pensamento utópico em texto anterior (Miguel, 1999a).
4 Embora a norma principal da ética utilitarista, "a maior felicidade para o maior número", seja condenada pelo individualismo radical dos anarcocapitalistas.

5 Nozick - que, no entanto, pára um passo antes do anarcocapitalismo, defendendo não a abolição do Estado, mas um "Estado ultramínimo" - chega a afirmar expressamente que uma sociedade livre não pode impedir que seus cidadãos se vendam em escravidão (Nozick, 1991 [1974], p. 155).

6 Embora freqüentemente ignorada pela discussão política corrente, os horizontes temporais diferenciados dos diversos grupos etários levantam uma série de problemas interessantes para a organização da democracia e a realização da justiça. Para uma síntese do debate, ver Van Parijs (1998).

7 Gorz revela concordância com uma idéia de Engels, muito criticada, segundo a qual a tirania da grande indústria é uma necessidade técnica "independente de toda organização social” (Engels, s.d. [1873], p. 186).

8 A visão de Gorz é, neste aspecto, limitada. Mais do que uma ideologia, trata-se de uma necessidade própria do capital: "A expansão em si não é apenas uma função econômica relativa (mais ou menos louvável e livremente adotada sob esta luz em determinadas circunstâncias, e conscientemente rejeitada em outras), mas uma maneira absolutamente necessária de deslocar os problemas e contradições que emergem no sistema do capital" (Mészáros, 1995, p. 176).

9 Em seu livro mais recente, ele anota que um "neoproletariado pós-industrial", correspondente à nãoclasse antes indicada, é o protagonista das contestações radicais ao capitalismo mundializado (Gorz, 2003, pp. 92-93).

10 Na citação, corrigi o equívoco evidente da tradução brasileira, que substitui "competição" por "participação" e vice-versa.

11 Em seu livro mais recente - no qual o tema é tratado apenas superficialmente -, o autor já apresenta uma adesão à proposta de renda básica incondicional bem mais desprovida de ressalvas (Gorz, 2003, pp. 99-104).

12 Uma das conseqüências negativas esperadas em caso de aumento da rotatividade nos cargos públicos, por exemplo, é a ampliação do poder da burocracia, que teria maior familiaridade com seu trabalho e, portanto, um saber superior. Como na utopia lotérica a burocracia também carece de permanên- 
cia, tal problema não existe, mas ao mesmo tempo desaparecem os benefícios advindos da presença de um grupo com experiência nas suas funções.

13 Parte dos estudos pode ser encontrada na página do BIEN na internet (www.basicincome.org). 


\section{UTOPIAS DO PÓS-SOCIALISMO: ESBOÇOS E PROJETOS DE REORGANIZAÇÃO RADICAL DA SOCIEDADE}

Luis Felipe Miguel

Palavras-chave: Utopia; Socialismo; Mercado; Liberdade; Igualdade.

Este artigo analisa propostas utópicas apresentadas nas últimas décadas, que projetam alternativas ao capitalismo diante do colapso da experiência socialista. Nenhuma alcança a centralidade que o socialismo teve, o que se deve menos à incipiência das formulações do que à ausência de conexões com um movimento social. São discutidas quatro propostas: o socialismo de mercado (Roemer), que busca combinar a "eficiência" do mercado com a garantia de igualdade real; a sociedade de tempo liberado (Gorz), que realizaria os objetivos do comunismo desenvolvido de Marx; a renda cidadã (Van Pariis), que também universalizaria a possibilidade de dispor de tempo livre; e a sociedade lotérica (Goodwin), em que os bens sociais seriam distribuídos pelo acaso. Como contraponto, é discutida também a utopia anarcocapitalista, que prevê a absorção de todas as funções estatais pelo mercado.

\section{POST-SOCIALISM UTOPIAS: PATTERNS AND PLANS OF RADICALLY REORGANIZING SOCIETY}

Luis Felipe Miguel

Keywords: Utopia; Socialism; Market; Freedom; Equality.

This article analyzes utopian proposals presented in the last decades that devise alternatives to capitalism in face of the failure of Socialism. None of them attains the centrality that Socialism had, which is less a sign of their theoretical weakness than it is a sign of the absence of connections towards social movements. Four proposals are discussed: market Socialism (Roemer), which attempts to combine market "efficiency" and the guarantee of real equality; the society of liberated time (Gorz), which will realize the aims of Marx's developed Communism; basic income (Van Parijs), that could also universalize the possibility of disposing free time; and the lottery society (Goodwin), in which chance would distribute all social goods. As a counterpoint, it is discussed also the anarcho-capitalist utopia, which foresees the absorption of all State functions by market.

\section{UTOPIES DU POST-SOCIALISME: ÉBAUCHES ET PROJETS DE REORGANISATION RADICALE DE LA SOCIÉTÉ}

Luis Felipe Miguel

Mots-clés: Utopie; Socialisme; Marché; Liberté; Égalité.

L'article analyse quelques propositions utopiques qui ont été présentées pendant les dernières décennies et qui proposent des alternatives au capitalisme suite à l'écroulement de l'expérience socialiste. Aucune d'elles ne parvient au centralisme du socialisme, ce qui peut indiquer la faiblesse de leurs formulations et, surtout, l'absence de rapport avec un mouvement social. Quatre propositions y sont discutées: le socialisme de marché (Roemer), qui veut combiner l'"efficacité" du marché avec une garantie d'égalité réelle ; la société de temps libéré (Gorz), qui accomplirait les buts du communisme développé par Marx ; le revenu citoyen (Van Parijs), qui universaliserait aussi la possibilité d'avoir du temps libre ; et la société de loterie (Goodwin), dans laquelle les biens collectifs seraient tous distribués au hasard. Comme contrepoint, l'article aborde également l'utopie anarchiste capitaliste, selon laquelle toutes les fonctions de l'État doivent être absorbées par le marché. 